\title{
Zmeny krajinnej pokrývky vo vel'kých mierkach s využitím starých máp: prípadová štúdia mestskej časti Bratislava-Devín
}

\author{
Filip MORAVČÍK, Alexandra BENOVÁ
}

\author{
Large-scale land cover changes based on old maps: case study of the Bratislava-Devin \\ city district
}

\begin{abstract}
The maps record a generalized state of a landscape at a particular time. Therefore, the old maps are useful for the study of land cover changes. More recent land cover state is captured by the orthophotomaps showing the reality without generalisation. However, there are limitations with this source of spatial information to identify certain objects in the forest, such as rivers or unpaved roads. The paper aims to present a detailed reconstruction of land cover changes, including the characteristics of each change that has occurred in a case study of the Bratislava-Devin city district. Five different map sources were used covering the period from 1920 to 2009 from the newest to the oldest: Slovak state database for the geographic information system (ZBGIS), digital orthophotomap of the Slovak Republic (DGO SR), Basic map of the Slovak Republic (ZM SR), Military topographic map in the Gauss-Krüger projection (TM G-K), and the Third military survey maps of the Habsburg Empire in an updated version (VTM). Mapping of land cover changes was performed at the fifth hierarchical level of the Corine Land Cover at a scale of 1:10,000. First, the maps were individually visually interpreted and individual land cover classes were identified. Further, the land cover changes were identified by retrospective comparison of the individually interpreted maps approaching from youngest to oldest. The results show a significant occurrence of orchards and vineyards in the monitored area and the occurrence of several processes: urbanization, intensification of agriculture, and afforestation.
\end{abstract}

Keywords: land cover changes, fifth hierarchical level of CLC, old maps, Bratislava-Devín

\section{Úvod}

Problematike krajinnej pokrývky je v súčasnej dobe venovaná značná pozornost'. Túto skutočnost' možno zdôvodnit' tým, že jej štruktúra má priamy vplyv na charakter prostredia, v ktorom sa vykonávajú l’udské aktivity. Dôležitou oblast'ou výskumu sú aj zmeny krajinnej pokrývky, ktoré majú dosah na celkový ráz krajiny. Ked’že krajina podlieha v súčasnej dobe, najmä vplyvom rôznych l’udských činností, výrazným zmenám, je žiadúce sa touto problematikou zaoberat'.

Pod pojmom krajinná pokrývka rozumieme určitú formu zhmotneného priemetu prírodných priestorových skutočností spolu so súčasným využívaním krajiny. Krajinná pokrývka je istou formou deskripcie - opisu jednotlivých prvkov, ktoré sa nachádzajú na zemskom povrchu (Feranec a Ot’ahel 2001). Poznanie krajinnej pokrývky bolo v nedávnej minulosti budované zväčša na topografických a tematických podkladoch, štatistických zist'ovaniach, ktoré boli realizované v pravidelných intervaloch, či metódach terénneho prieskumu. Problém takto získaných údajov však spočíval v ich vzájomnej nekonzistencii, a to z rôznych hl'adísk: priestorových, obsahových a časových. Tento aspekt čiastočne zredukovali až metódy dial'kového prieskumu Zeme (DPZ), ktoré poskytli väčšiu kvalitu a s tým súvisiacu presnost' získaných údajov (Šrúri 2003 in Ivanová 2013).

DOI: https://doi.org/10.33542/GC2020-2-03 
Zmenám krajinnej pokrývky sa venujú mnohé práce domácich autorov (napr. Kopecká 2006, Ivanová, Michaeli a Boltižiar 2013, Druga, Falt’an a Herichová 2015, Pazúr a Bolliger 2017, Falt’an et al. 2018), ale aj zahraničných (napr. Gerard et al. 2010, Braccheti, Carotenuto a Catorci 2012, Di Gregorio a O Brien 2012, Goundaridis, Apostolou a Koukoulas 2015, Munteanu et al. 2017). Ako uvádza Kopecká (2006), autori využívajú pri svojich výskumoch rôzne metódy, pomocou ktorých analyzujú krajinnú pokrývku vybraného územia vo viacerých časových radoch a poukazujú na konzekvencie procesov, ktorých výskyt bol pozorovaný v danom území. Taktiež sledujú intenzitu týchto procesov a ich vplyv na štruktúru krajiny. Poznanie jednotlivých procesov prebiehajúcich v krajine je dôležité, avšak pozornost' je potrebné sústredit' aj na poznanie príčinných súvislostí. Hodnoteniu krajinnej pokrývky z hl'adiska ekologickej stability krajiny sa venuje príspevok Ivanovej et al. (2013), pričom výskum bol realizovaný v dvoch rozličných lokalitách.

V prípade krajinnej pokrývky zohráva dôležitú úlohu projekt Corine Land Cover (CLC), ktorého hlavným ciel’om bolo vytvorit' ucelenú digitálnu databázu obsahujúcu informácie zaoberajúce sa krajinnou pokrývkou na území Európy. Mierka mapovania bola zvolená na úrovni 1:100 000. Pri vytváraní digitálnej databázy boli využité metódy DPZ. Dôležitou súčastou projektu bolo taktiež záväzné medzinárodné definovanie kategórií foriem krajinnej pokrývky (Falt'an 2005 in Falt'an et al. 2008). Ciel'om projektu Corine (Coordination of Information on the Environment) je teda integrovanie vel'kého množstva pokusov, ktoré boli uskutočnené na odlišných úrovniach. Dôraz je zameraný na orientované získavanie konkrétnych informácií súvisiacich s krajinou, ako aj na metódy ich výmeny. Údaje DPZ, ktoré dokumentujú hlavne rôzne fyziognomické charakteristiky určitých objektov vyskytujúcich sa na zemskom povrchu, sú mnohokrát následne využívané aj pri získavaní údajov týkajúcich sa krajinnej pokrývky. Zdroj údajov, ktorý bol využitý pri riešení tohto projektu, predstavovali obrazové záznamy, ktoré boli vytvorené satelitom Landsat $5 \mathrm{TM}$, a následne upravené do analógovej formy (Feranec a Ot'ahel 1995). Nomenklatúra projektu CLC má tri záväzne definované úrovne. V súčasnosti je však kladený dôraz na výskum v podrobnejších úrovniach, a to najmä vo štvrtej a piatej. S touto skutočnost'ou úzko súvisí aj tendencia mapovania vo vel'kých mierkach (1:10 000). Niekol'ko autorov vytvorilo a publikovalo vlastné členenie tried na podrobnejších úrovniach mapovania (štvrtej, resp. piatej úrovni), a to napr. Feranec a Ot’ahel (1999), Kopecká (2006), Druga, Falt’an a Herichová (2015) a i. Za jeden z najnovších a najkomplexnejších príspevkov k danej problematike možno považovat' modifikáciu v oblasti vyčlenenia tried od Ot’ahela et al. (2017), kde autori definovali celkovo 90 tried štvrtej hierarchickej úrovne.

Analýze zmien krajinnej pokrývky sa tiež venovali napr. Kandrík a Oláh (2010), ktorí skúmali historické katastrálne mapy, prípadne autori, ktorí skúmali krajinnú pokrývku na malých územiach, pričom ich hlavným ciel’om bola deskripcia jednotlivých zmien krajinnej pokrývky (Rábeková 2008, Cebecauerová a Cebecauer 2008). Skúmaniu krajinnej pokrývky pomocou historických mapových podkladov sa venovali aj Kolejka a Marek (2004), Olah (2005), Izakovičová, Mederly a Petrovič (2017). Analýzu transformácie krajiny v prípade rozdelenia na štyri typy: nížiny, povodia, doliny medzi horami a hory; s následným určením trendov, ponúka štúdia Boltižiara et al. (2016). Autorský kolektív Lieskovský et al. (2018) prezentujú digitálnu mapu využívania územia zobrazujúcu územie siedmich krajín, pričom autori využili hierarchickú legendu, ktorá obsahovala štyri úrovne.

Porovnanie zistených výsledkov s inými výskumnými prácami prináša určité opakujúce sa trendy. Kopecká (2006) uvádza, že na základe najnovších mapových podkladov vo forme ortofotosnímok je možné detailnejšie identifikovat' a vyčlenit' triedy krajinnej pokrývky, najmä v súvislosti s podrobnejším mapovaním vo vel'kých mierkach. Výskyt konkrétnych tried priamo závisí od územia, na ktorom sa realizuje výskumný projekt, a preto je vel'mi náročné, priam takmer nemožné, zamerat' sa na výskyt určitých vytypovaných tried krajinnej pokrývky - tento postup by bolo možné aplikovat' $v$ prípade podobnosti sledovaného územia $\mathrm{v}$ čo najväčšom počte jeho charakteristík. Druga, Falt’an a Herichová (2015) uvádzajú skutočnost', že v prípade rozhodnutia realizovat' výskum na podrobnejšej úrovni CLC vo vel'kej mierke je možné očakávat' nárast počtu jednotlivých identifikovaných tried krajinnej pokrývky. 
Ciel’om príspevku je predostriet' historické zmeny krajinnej pokrývky na vybranej časti územia mestskej časti Bratislava-Devín v období rokov 1920 až 2009 na základe piatich rôznych podkladov. Mapovanie zmien krajinnej pokrývky sa uskutočnilo na piatej hierarchickej úrovni CLC v mierke 1:10 000. Snahou bolo ukázat', kol'ko informácií je možné získat' analýzou historických topografických máp v spojitosti so zmenami krajiny. Predkladaný príspevok prezentuje čast' výsledkov z experimentu bakalárskej práce (Moravčík 2017).

\section{Metódy a údaje}

Pri realizácii výskumu boli použité dve hlavné metódy. Prvou bola historicko-geografická metóda, a to vo forme metódy retrospektívnej analýzy. Základom tejto metódy je vizuálne interpretovaný najnovší podklad vopred určeného časového radu. Tento podklad je následne porovnávaný so staršími podkladmi (Kan̆uk et al. 2015, Grežo 2012). Samotné zaznamenávanie jednotlivých tried krajinnej pokrývky, a taktiež ich následných zmien, bolo realizované na základe metódy vizuálnej interpretácie (Falt’an et al. 2018). Okrem dvoch t’ažiskových metód boli využité aj d’alšie parciálne metódy, a to: komparatívna metóda - porovnávanie jednotlivých údajov za časové obdobia; štatistická metóda - kvantitatívne vyjadrenie výsledkov práce; systémová metóda - vo forme logickej následnosti pri realizácii jednotlivých krokov (Dubcová et al. 2013).

Spracovávanými mapovými podkladmi boli: Základná báza údajov pre geografický informačný systém (ZBGIS), Digitálna ortofotomapa Slovenskej republiky (DGO SR), Základná mapa Slovenskej republiky (ZM SR), Topografická mapa v Gauss-Krügerovom zobrazení (TM G-K) a najstarší použitý mapový podklad, ktorý predstavovala mapa Tretieho vojenského mapovania $\mathrm{v}$ jej reambulovanej verzii (VTM). Využitie najstaršieho mapového podkladu možno označit' za experimentálne z hl'adiska nášho výskumného zámeru, ked’že bol vyhotovený v mierke 1:25 000. Obsahová stránka zobrazených prvkov na jednotlivých historických mapách sa javila ako dostatočná pre naše potreby. Mapový podklad VTM bol interpretovaný na základe prác Jankó a Porubská (2013) a Zhorela (1949). V prípade ZM SR a TM G-K boli použité mapové podklady v mierke 1:10 000, pričom ich interpretácia bola realizovaná podl'a mapových klúčov ku danej mierke ZM SR (Zoznam mapových značiek 1972) a TM G-K (Dohodnuté značky topografických máp 1959). Použitie zvolených mapových podkladov umožnilo dokumentovat' krajinnú pokrývku na záujmovom území v rozsahu takmer 90 rokov (1920 až 2009). Tri najstaršie mapové podklady predstavujú topografické mapy a boli použité vo forme vol'ne dostupných WMS vrstiev (WMS SAŽP 2018). DGO SR bola dostupná vo forme rastra (.jpg), ktorý vyhotovili spoločnosti Eurosense s. r. o., Bratislava a spoločnost' Geodis Slovakia s. r. o., Banská Bystrica. Udaje ZBGIS boli použité vo vektorovej forme (.shp) a ich zhotovitel'om a vlastníkom je Úrad geodézie, kartografie a katastra Slovenskej republiky (ÚGKK SR) (ZBGIS 2018).

Je potrebné zdôraznit', že v prípade využitia historických máp v súvislosti s interpretáciou zmien krajinnej pokrývky, je nutné zvážit' charakter a vhodnost' konkrétneho podkladu z hl'adiska jeho obsahovej náplne a znázornenia jednotlivých prvkov súvisiacich s krajinnou pokrývkou, spolu so skutočnost’ou, či záujmová oblast' dosahuje na konkrétnom území dostatočnú rozlišovaciu schopnost' pre potreby identifikácie tried krajinnej pokrývky, a to najmä pri mapovaní vo vel'kých mierkach. Ako uvádza Falt’an et al. (2018), mapové zdroje sú vhodným podkladom pre výskum krajinnej pokrývky, pričom tieto sú v súčasnej dobe využívané na zaznamenanie vývoja krajinnej pokrývky v období posledných približne 200 rokov, a to najmä z dôvodu detailnosti zobrazenia a jednoduchšej orientácie $\mathrm{v}$ teréne v porovnaní s leteckými alebo satelitnými snímkami. Mapové zdroje zároveň slúžia na detailné zaradenie konkrétnych objektov do jednotlivých tried, pričom však treba zvážit’ rôznu kvalitu vstupných dát.

Prvým krokom experimentu bolo spracovanie vyššie uvedených vstupných údajov. V prípade DGO SR a mapových podkladov vo forme WMS bolo nevyhnutné zrealizovat' vektorizáciu územia na základe metódy vizuálnej interpretácie. So samotnou vektorizáciou úzko súvisí 
aj polohová presnost' mapových podkladov, a to z dôvodu, aby bolo možné pomerne jednoznačne určit', či ide o zmenu triedy krajinnej pokrývky alebo iba o polohovú nepresnost' podkladu. S vektorizáciou podkladov následne súvisí aj stanovenie minimálnej mapovacej jednotky (Husár 1996). V našom prípade bola minimálna mapovacia jednotka určená na úrovni $30 \mathrm{~m}^{2}$. Táto hodnota súvisí s rozlišovacou schopnost'ou oka, ktorá je na úrovni 2 mm (Pravda 2003). Taktiež, minimálna mapovacia jednotka by mala byt' na úrovni, ktorá je desat'násobne väčšia, ako je vel'kost' 1 px (Mičietová a Kožuch 2008). Vektorizácia prebiehala na základe mapového kl’úča, ktorý bol prezentovaný v práci Kopeckej (2006). Autorka vo svojom príspevku vychádzala zo štvrtej hierarchickej úrovne prezentovanej v práci Feranca a Ot’ahela (1999). V našom prípade bola urobená mierna modifikácia v súvislosti s cestnou sietou, ku ktorej sa pristúpilo z dôvodu čo možno najpresnejšej interpretácie jednotlivých prvkov vyskytujúcich sa na danom území, a taktiež z dôvodu zachytenia celkového charakteru územia. Pôvodné delenie Kopeckej v prípade cestnej siete bolo na: Cesty a pril'ahlé areály bez súvislej sprievodnej drevinovej vegetácie; Cesty a pril'ahlé areály lemované stromoradiami; Dialnica; Cestná siet'v sídlach. V našom prípade sme sa rozhodli vyčlenit' vlastné triedy: Spevnená cestná siet' a pril'ahlé areály; Lesné alebo polné cesty; Cyklistické chodníky; Parkoviská. Vyčlenenie vlastných tried bolo realizované preto, aby bolo možné identifikovat' základné diferencie medzi jednotlivými prvkami cestnej siete vyskytujúcimi sa na skúmanom území. Avšak, aby dané členenie cestnej siete nebolo iba úzko naviazané na skúmané územie, bol pri vyčlenení tried taktiež zohl’adnený faktor ich prípadného budúceho využitia aj pri iných záujmových územiach. Po vektorizácii plôch za jednotlivé časové obdobia sa pristúpilo k porovnávaniu zistených zmien pomocou nástroja Intersect, vd'aka ktorému bolo možné zaznamenat' jednotlivé zmeny a porovnania tried krajinnej pokrývky naprieč mapovými podkladmi. Použitým technologickým prostredím bol vol’ne dostupný geografický informačný systém QGIS vo verzii 3.4.

\section{Skúmané územie}

Geografickú polohu mestskej časti Bratislava - Devín možno definovat' pomocou súradníc, konkrétne $16^{\circ} 58^{\prime}$ v. g. d. a $48^{\circ} 10^{\prime}$ s. g. š. Mestská čast' je súčast’ou okresu Bratislava IV a jej rozloha je viac ako $14 \mathrm{~km}^{2}$. Skúmanie zmien krajinnej pokrývky prebehlo na vybranej časti územia mestskej časti, ktorá mala rozlohu $2,61 \mathrm{~km}^{2}$ (obr. 1). Výber územia spočíval najmä v predpoklade najväčších zmien krajinnej pokrývky vo zvolenej oblasti mestskej časti, a taktiež výskytu značnej variability jednotlivých tried krajinnej pokrývky v tejto oblasti, ked’že ide o zastavanú čast' a jej najbližšie okolie. Nemenej dôležitým faktorom bola vhodnost' územia z hl'adiska použitých mapových podkladov.

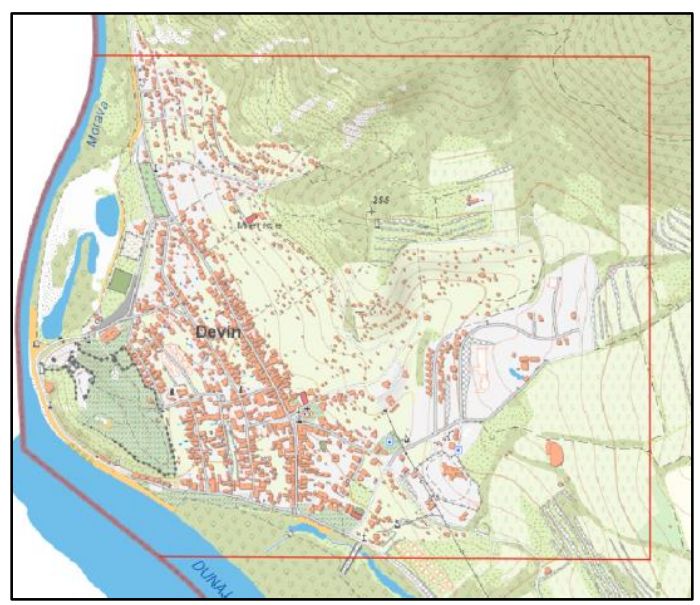

Obr. 1. Vymedzenie skúmaného územia; Zdroj: ZBGIS (2018) 


\section{Výsledky}

Najstarším použitým mapovým podkladom je mapa Tretieho vojenského mapovania v reambulovanej verzii (VTM), pomocou ktorej bola charakterizovaná historická krajinná pokrývka v období rokov 1920 - 1934 (obr. 2). Na uvedenom mapovom podklade sa podarilo identifikovat' 11 rôznych tried piatej hierarchickej úrovne CLC. Čo sa týka plošného zastúpenia, tak najväčšiu rozlohu zaznamenali trávne porasty s rozptýlenými stromami a krami $(110,84$ ha, čo predstavuje $42,49 \%$ z rozlohy záujmového územia), nasledované intenzivnymi ovocnými sadmi (83,60 ha; $32,05 \%)$. Naopak, najmenšou identifikovanou triedou, čo sa týka rozlohy, bola trieda riečne a jazerné prístavy (0,05 ha; 0,02 \%). Spevnená cestná siet' nadobudla dížku viac ako 4,7 km, lesné alebo pol'né cesty nadobudli až takmer $9,3 \mathrm{~km}$. Za zaujímavý fakt môžeme považovat', že na skúmanom území sa v období rokov 1920 - 1934 nevyskytovali žiadne vinice.

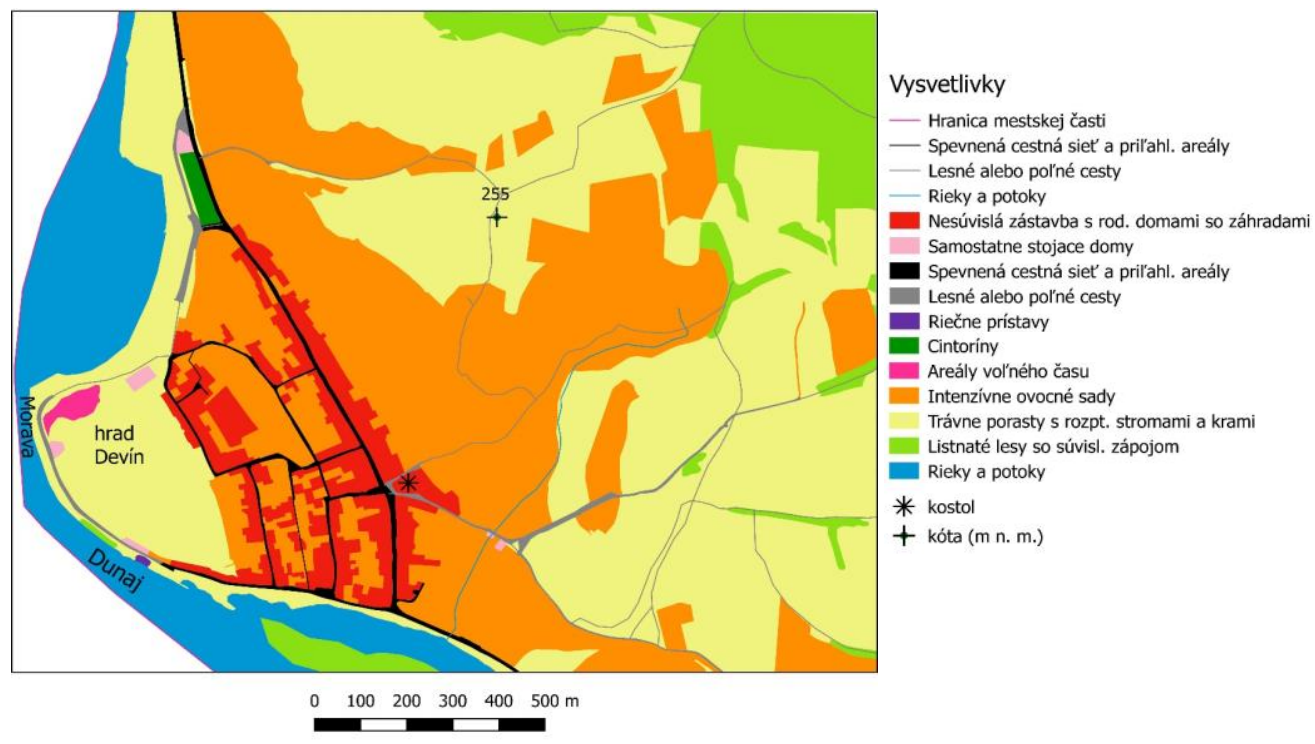

Obr. 2. Krajinná pokrývka v období rokov 1920 - 1934;

Zdroj: WMS SAŽP (2016); vlastné spracovanie

Ďalším použitým mapovým podkladom bola Topografická mapa v Gauss-Krügerovom zobrazení (TM G-K), na ktorej základe bola zrekonštruovaná krajinná pokrývka z obdobia 1957 - 1971 (obr. 3). Identifikovaných bolo spolu 17 tried krajinnej pokrývky. Najväčšiu rozlohu opät' dosiahli trávne porasty s rozptýlenými stromami a krami (87,64 ha; 33,59 \%). Tieto boli nasledované intenzívnymi ovocnými sadmi (70,29 ha; 26,94 \%) - rovnako, ako v predchádzajúcom prípade. Plošne najmenšou triedou boli samostatne stojace domy $(0,53$ ha; 0,20 \%). Spevnená cestná siet' mala dížku takmer $5,2 \mathrm{~km}$; lesné alebo polné cesty boli v dížke viac ako $11,6 \mathrm{~km}$. TM G-K už znázorňovala areály viníc, a taktiež sa podarilo zaznamenat' výskyt vel'koplošne obrábanej ornej pôdy s vel'kými parcelami (15,04 ha, 5,77 \%) - pričom výskyt tejto triedy na predchádzajúcom podklade absentoval. Zaznamenaná bola tiež absencia výskytu riečneho a jazerného prístavu. Dôvod môže byt' rôzny, napríklad nefunkčnost' tohto prístavu počas sledovaného obdobia alebo taktické neznázornenie, a to najmä z dôvodu, že poloha prístavu je v tesnej blízkosti štátnej hranice.

Nasledujúcim analyzovaným podkladom bola Základná mapa SR (ZM SR), ktorá charakterizuje obraz krajiny v rokoch 1971 - 1986 (obr. 4). Početnost' jednotlivých tried krajinnej pokrývky nadobudla hodnotu 18 . Charakter tried je podobný ako v predchádzajúcich prípadoch - opät' bola zaznamenaná dominancia trávnych porastov s rozptýlenými stromami a krami (74,50 ha, resp. 28,56 \%) a intenzívnych ovocných sadov (58,21 ha, 22,31\%); naopak 
najmenšie plošné zastúpenie dosiahli cintoríny (0,61 ha; 0,23 \%). Spevnená cestná siet' dosiahla takmer $8,47 \mathrm{~km}$; lesné alebo pol'né cesty viac ako $8,64 \mathrm{~km}$. Podobne, ako u predchádzajúceho mapového podkladu, bola zaznamenaná absencia znázornenia prístavu.
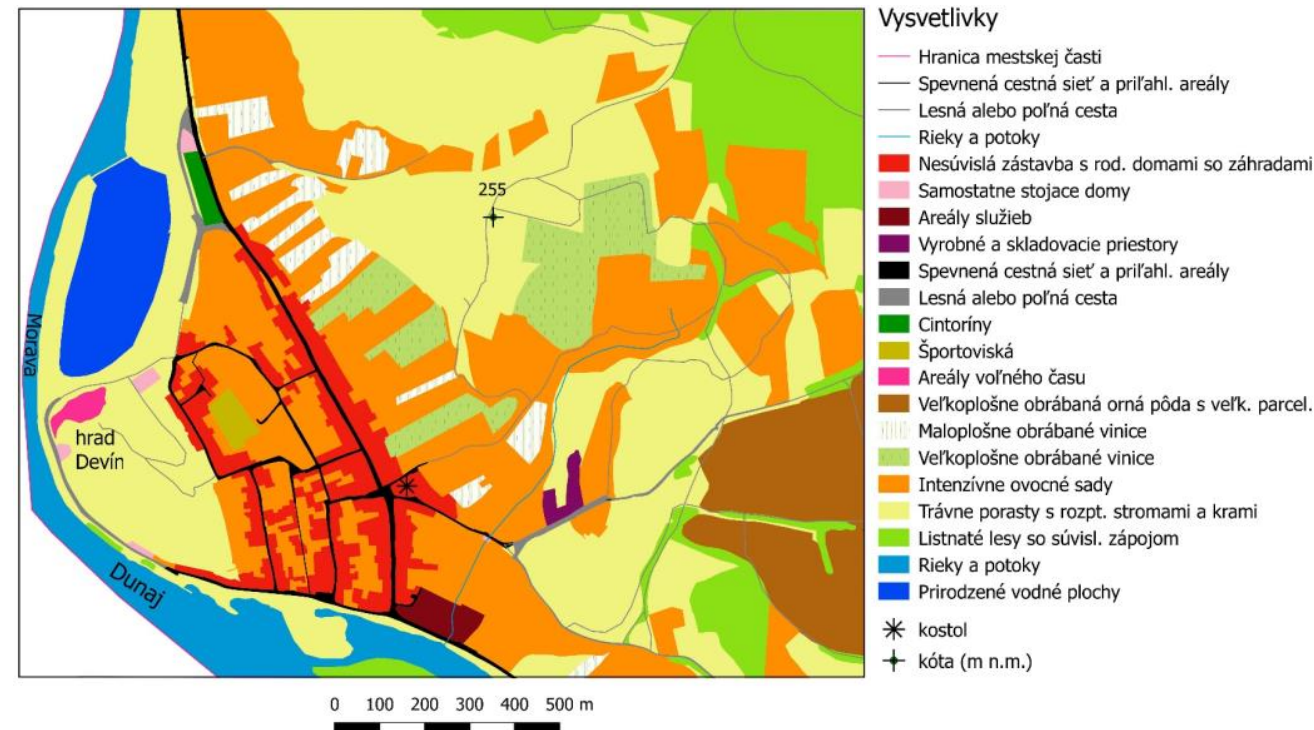

Obr. 3. Krajinná pokrývka v období rokov 1957 -1971;

Zdroj: WMS SAŽP (2016); vlastné spracovanie
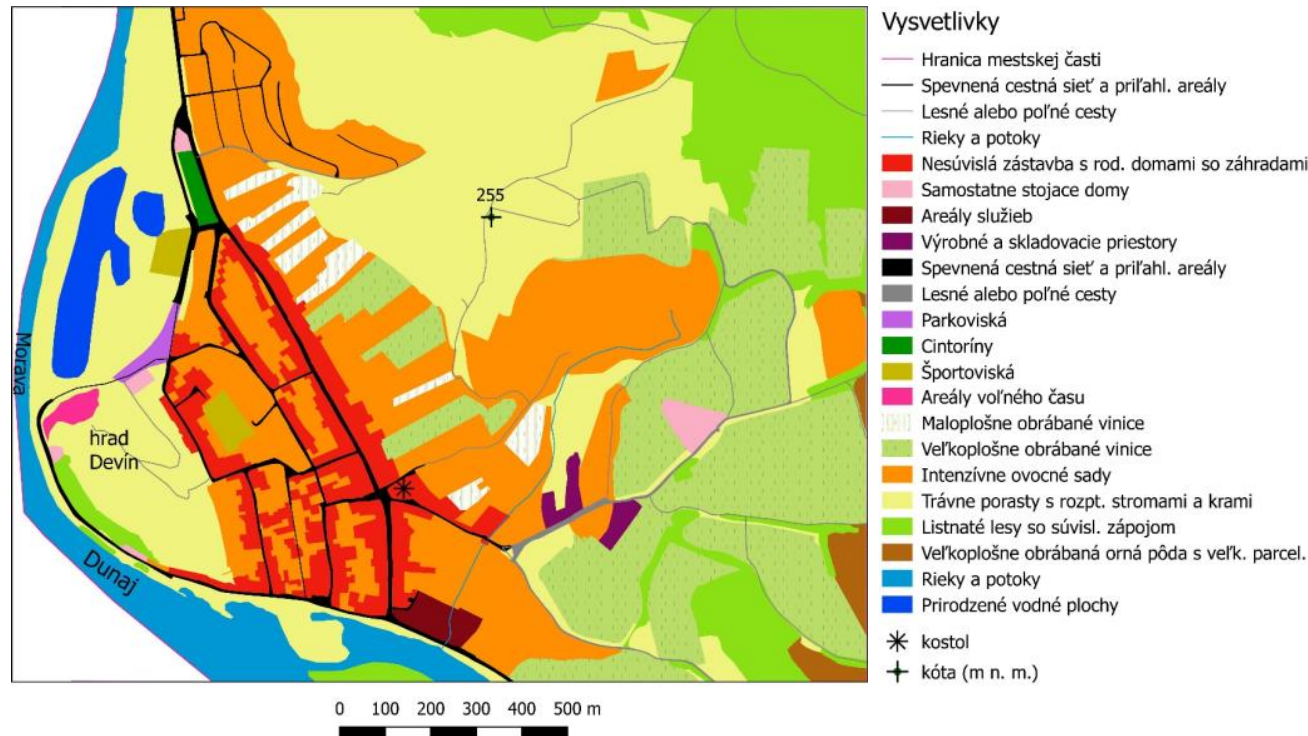

Obr. 4. Krajinná pokrývka v období rokov 1971 - 1986;

Zdroj: WMS SAŽP (2016); vlastné spracovanie

Charakter krajinnej pokrývky v období rokov 2002 - 2003 bol rekonštruovaný na základe Digitálnej ortofotomapy SR (DGO SR) pričom sa podarilo zaznamenat' výskyt 24 tried (obr. 5). Rozlohou najväčšou triedou boli listnaté lesy so súvislým zápojom (59,79 ha; 22,92\%). Tieto boli nasledované intenzívnymi ovocnými sadmi (57,80 ha; 22,16 \%). Najmenšiu rozlohu mali umelé vodné plochy $(0,01$ ha; $0,004 \%)$. Spevnená cestná siet' bola v dížke viac ako 12,7 km; 
lesné alebo pol’né cesty v dížke takmer 5,52 km. Na základe skutočnosti, že DGO SR je obsahovo vel'mi podrobný mapový podklad, sa podarilo identifikovat' niekol'ko tried krajinnej pokrývky, ktoré na predchádzajúcich podkladoch absentovali (napr. močiar, areál skládky). Za zmienku stojí fakt, že vel'koplošne obrábanú ornú pôdu s vel'kými parcelami sa na tomto podklade v záujmovom území nepodarilo identifikovat', čo bolo pravdepodobne spôsobené rozdrobením jednotlivých parciel počas sledovaného obdobia. Toto rozdrobenie mohlo byt' následkom zmeny prístupu k celkovému charakteru pol'nohospodárstva v dôsledku zmeny politického systému.

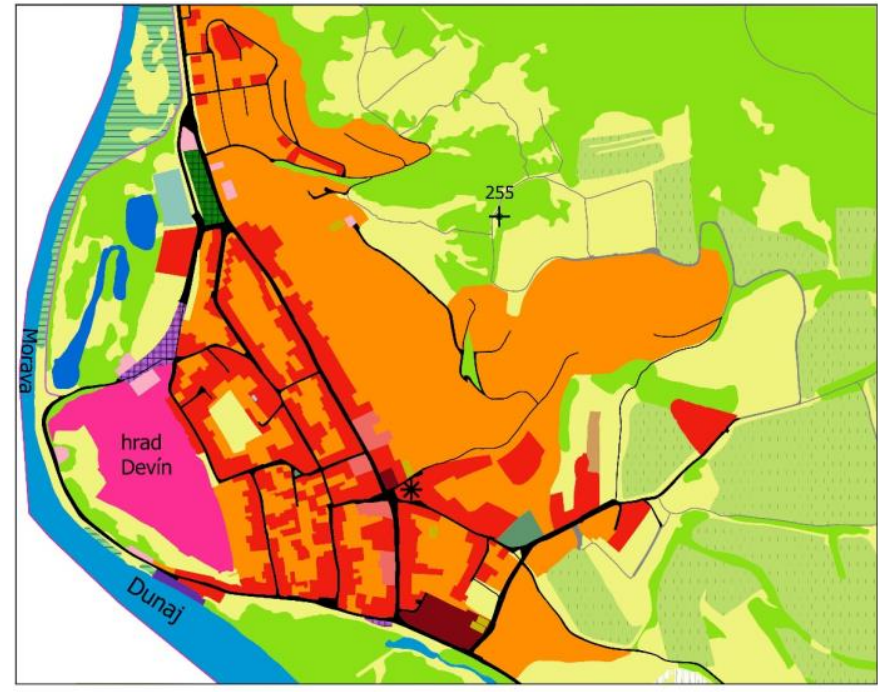

$0 \quad 100 \quad 200 \quad 300 \quad 400 \quad 500 \mathrm{~m}$

Obr. 5. Krajinná pokrývka v období rokov 2002 - 2003;

Zdroj: Ortofotomapa (2005); vlastné spracovanie

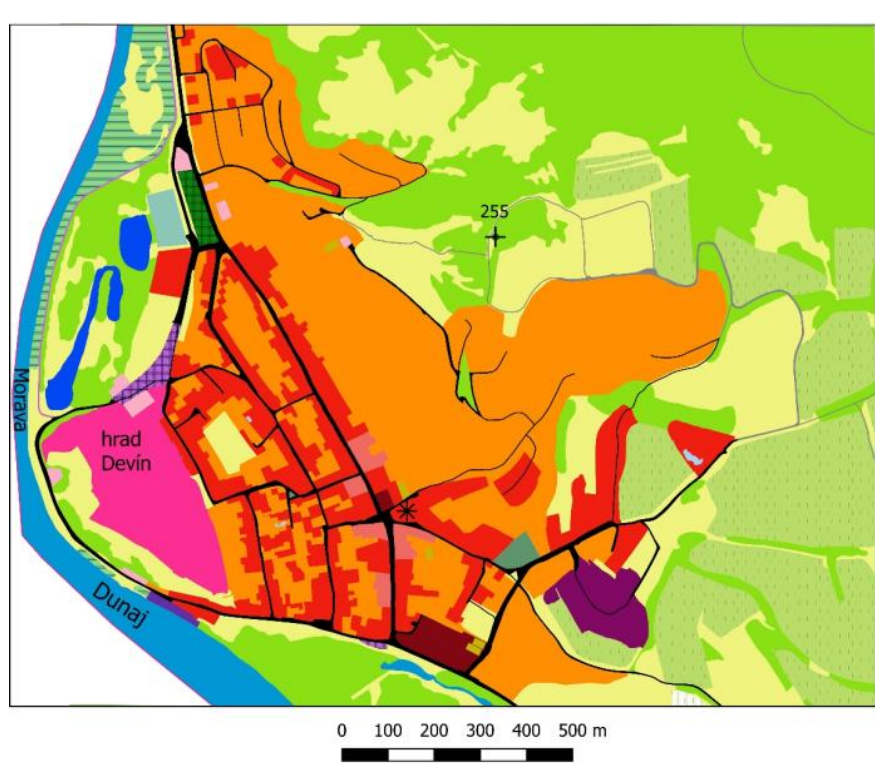

Vysvetlivky

Obr. 6. Krajinná pokrývka v roku 2009; Zdroj: ZBGIS (2009); vlastné spracovanie 
Najnovšie mapové údaje poskytovala Základná báza údajov pre geografický informačný systém (ZBGIS), konkrétne jej verzia z roku 2009. Krajinná pokrývka v sledovanom období bola tvorená 24 triedami - totožný počet s DGO SR (obr. 6). Najväčšie plošné zastúpenie nadobudli listnaté lesy so súvislým zápojom (60,21 ha; 23,08\%), rovnako nasledované intenzívnymi ovocnými sadmi $(57,80$ ha; čo je $22,16 \%)$. Najmenšiu rozlohu zaznamenali umelé vodné plochy $(0,09$ ha; $0,03 \%)$. Na základe uvedených skutočností je možné pozorovat' pomerne vel'kú podobnost', čo sa týka plošného zastúpenia a dominancie tried krajinnej pokrývky, medzi údajmi ZBGIS a DGO SR. Táto skutočnost' je pravdepodobne dôsledkom nie tak vel'kého časového diapazónu medzi uvedenými podkladmi.

\section{Zmeny krajinnej pokrývky}

Analýza zmien krajinnej pokrývky prebiehala medzi jednotlivými dvojicami mapových podkladov, pričom ako prvé bolo realizované porovnávanie medzi mapou VTM a TM G-K. V tomto prípade bol zaznamenaný prírastok v podobe siedmich tried krajinnej pokrývky spolu s úbytkom vo forme jednej triedy. Najväčší plošný prírastok bol v prípade vel'koplošne obrábanej ornej pôdy s vel'kými parcelami (15,04 ha) a vel'koplošne obrábaných viníc (11,23 ha). Naopak, najväčší úbytok bol dokumentovaný v prípade trávnatých porastov s rozptýlenými stromami a krami (23,20 ha) a intenzívnych ovocných sadov (13,31 ha). Co sa týka líniových prvkov, tak spevnená cestá siet' sa rozšírila o takmer $0,5 \mathrm{~km}$ a lesné alebo polné cesty o viac ako 2,3 km.

Porovnávanie realizované medzi TM G-K a ZM SR ukázalo prírastok vo forme výskytu jednej triedy (parkoviská), pričom úbytok tried nebol zaznamenaný. Najväčší plošný nárast dosiahli vel'koplošne obrábané vinice (34,92 ha). Najväčší úbytok dosiahli trávne porasty s rozptýlenými stromami a krami $(13,14$ ha) a intenzívne ovocné sady $(12,08$ ha) - totožná situácia, ako v prípade predchádzajúceho porovnávania. Dížka spevnenej cestnej siete narástla až o takmer $3,3 \mathrm{~km}$. Naproti tomu, lesné alebo polné cesty ubudli o takmer $3 \mathrm{~km}$. Uvedená skutočnost' pravdepodobne súvisí s tým, že bolo v tomto období postupne realizované nahradzovanie pol’ných a lesných ciest spevnenými cestami. Na oboch porovnávaných mapových podkladoch boli pomerne podrobne znázornené aj málo využívané lesné a pol’né cesty.

Zmeny krajinnej pokrývky medzi ZM SR a DGO SR boli najpočetnejšie. Tento fakt spôsobila najmä rozlišovacia schopnost' v prípade DGO SR. Bol zaznamenaný prírastok až ôsmich tried a úbytok dvoch. Najväšší prírastok zaznamenali listnaté lesy so súvislým zápojom (31,61 ha), nasledované nesúvislou sídelnou zástavbou s rodinnými domami so záhradami (7,38 ha). Najväčší úbytok dosiahli trávne porasty s rozptýlenými stromami a krami $(31,61$ ha) a vel'koplošne obrábané vinice (13,21 ha). Podarilo sa identifikovat' súvislú zástavbu vo vidieckych sídlach a v okrajových častiach miest, ktorá nadobudla plošnú rozlohu 1,02 ha. Išlo o domy v radovej zástavbe, kde bola zaznamenaná malá vzdialenost’ medzi ich strechami, do $5 \mathrm{~m}$ (Kopecká 2006). Pri identifikácii tejto triedy sme postupovali rovnako ako Kopecká vo svojom príspevku, pričom spomenutá trieda krajinnej pokrývky vznikla pri podrobnejšom mapovaní z triedy nesúvislá sídelná zástavba. Bol zaznamenaný nárast dížky spevnenej cestnej siete o viac ako 4,2 km a naopak úbytok dížky lesných alebo polných ciest o viac ako $3,1 \mathrm{~km}$. Podarilo sa identifikovat' aj areál výstavby bývania (0,34 ha). Ked’že ide o dynamicky sa meniaci areál, podarilo sa ho zaznamenat' iba na jednom podklade.

Záverečné porovnanie zmien bolo realizované medzi DGO SR a ZBGIS. V tomto porovnaní bol zaznamenaný najmenší počet zmien. Bol identifikovaný úbytok jednej triedy, konkrétne sa jednalo o vyššie zmienený areál výstavby bývania. Najväčší plošný prírastok zaznamenali výrobné a skladovacie priestory (2,60 ha). Naopak, najväčší úbytok trávne porasty s rozptýlenými stromami a krami (3,18 ha). Taktiež bol zaznamenaný nárast spevnenej cestnej siete o viac ako $0,5 \mathrm{~km}$ a úbytok lesných alebo pol’ných ciest o viac ako $2,2 \mathrm{~km}$.

Cintorín, ako trieda krajinnej pokrývky, sa vyskytoval v nezmenenej podobe na všetkých mapových podkladoch. Môžeme teda konštatovat', že si svoju podobu zachováva v nezmenenej forme už takmer sto rokov. Jedná sa o jedinú triedu krajinnej pokrývky v prípade ktorej sa nezaznamenala počas celého sledovaného obdobia žiadna plošná zmena.

Sumárne sú znázornené prírastky jednotlivých tried krajinnej pokrývky v tab. 1 a úbytky tried krajinnej pokrývky v tab. 2. 
Tab. 1. Prírastok tried krajinnej pokrývky na piatej hierarchickej úrovni CLC (v ha)

\begin{tabular}{|c|c|c|c|c|}
\hline \multirow[b]{2}{*}{ Trieda krajinnej pokrývky (kód) } & \multicolumn{4}{|c|}{ Zmeny v období (v ha) } \\
\hline & \begin{tabular}{|c|}
$1920 / 1934-$ \\
$1957 / 1971$ \\
\end{tabular} & \begin{tabular}{|c|}
$1957 / 1971$ \\
$1971 / 1986$ \\
\end{tabular} & $\begin{array}{l}1971 / 1986 \\
2002 / 2003\end{array}$ & $\begin{array}{c}2002 / 2003- \\
2009\end{array}$ \\
\hline Súvislá zást. vo vidieckych sídlach a v okrajových častiach miest (11131) & 0 & 0 & 1,02 & 0,38 \\
\hline Nesúvislá zástavba s rodinnými domami so záhradami (11221) & 0 & 1,28 & 7,38 & 0,49 \\
\hline Samostatne stojace domy (11222) & 0 & 0,90 & 0 & 0 \\
\hline Areály služieb (12111) & 1,22 & 0 & 0,03 & 0 \\
\hline Výrobné a skladovacie priestory (12112) & 0,68 & 0,66 & 0 & 2,60 \\
\hline Spevnená cestná siet' a prilahlé areály (12211) & 0,35 & 1,77 & 1,74 & 0,13 \\
\hline Lesná alebo pol'ná cesta (12212) & 0,05 & 0 & 0 & 0 \\
\hline Cyklistické chodníky (12213) & 0 & 0 & 0,36 & 0 \\
\hline Parkoviská (12214) & 0 & 0,69 & 0,06 & 0 \\
\hline Riečne prístavy (12321) & 0 & 0 & 0,23 & 0 \\
\hline Skládky komunálneho a stavebného odpadu (13211) & 0 & 0 & 0,74 & 0 \\
\hline Výstavba areálov bývania (13312) & 0 & 0 & 0,34 & 0 \\
\hline Zeleň v okolí sídelných komunikácií (14131) & 0 & 0 & 0,46 & 0 \\
\hline Športoviská (14211) & 0,79 & 0,70 & 0 & 0 \\
\hline Areály vol'ného času (14221) & 0 & 0 & 7,45 & 0 \\
\hline Vel'koplošne obrábaná orná pôda s vel'kými parcelami (21113) & 15,04 & 0 & 0 & 0 \\
\hline Maloplošne obrábané vinice (22111) & 5,62 & 0 & 0 & 0 \\
\hline Vel'koplošne obrábané vinice (22112) & 11,23 & 34,92 & 0 & 0 \\
\hline Listnaté lesy so súvislým zápojom (31111) & 3,65 & 3,53 & 31,61 & 0,42 \\
\hline Brehové porasty (31112) & 0 & 0 & 3,35 & 0 \\
\hline Prirodzené vodné plochy (51211) & 8,01 & 0 & 0 & 0 \\
\hline Umelé vodné plochy (51221) & 0 & 0 & 0,01 & 0,08 \\
\hline
\end{tabular}

Zdroj: vlastné spracovanie

Tab. 2. Úbytok tried krajinnej pokrývky na piatej hierarchickej úrovni CLC (v ha)

\begin{tabular}{|c|c|c|c|c|}
\hline \multirow[b]{2}{*}{ Trieda krajinnej pokrývky (kód) } & \multicolumn{4}{|c|}{ Zmeny v období (v ha) } \\
\hline & \begin{tabular}{|l|}
$1920 / 1934-$ \\
$1957 / 1971$
\end{tabular} & $\begin{array}{c}1957 / 1971- \\
1971 / 1986\end{array}$ & \begin{tabular}{|c|}
$1971 / 1986-$ \\
$2002 / 2003$
\end{tabular} & \begin{tabular}{|c}
$2002 / 2003-$ \\
2009
\end{tabular} \\
\hline Nesúvislá zástavba s rodinnými domami so záhradami (11221) & 0,18 & 0 & 0 & 0 \\
\hline Samostatne stojace domy (11222) & 0,04 & 0 & 0,61 & 0 \\
\hline Výrobné a skladovacie priestory (12112) & 0 & 0 & 1,34 & 0 \\
\hline Lesná alebo pol'ná cesta (12212) & 0 & 1,02 & 0,52 & 0,13 \\
\hline Riečne prístavy (12321) & 0,05 & 0 & 0 & 0 \\
\hline Výstavba areálov bývania (13312) & 0 & 0 & 0 & 0,34 \\
\hline Športoviská (14211) & 0 & 0 & 1,25 & 0 \\
\hline Vel'koplošne obrábaná orná pôda s vel'kými parcelami (21113) & 0 & 12,63 & 2,41 & 0 \\
\hline Maloplošne obrábané vinice (22111) & 0 & 1,93 & 3,39 & 0,07 \\
\hline Vel'koplošne obrábané vinice (22112) & 0 & 0 & 13,21 & 0,91 \\
\hline Intenzívne ovocné sady (22212) & 13,31 & 12,08 & 0,41 & 0 \\
\hline Trávne porasty s rozptýlenými stromami a krami (23121) & 23,20 & 13,14 & 31,61 & 3,18 \\
\hline Rieky a potoky (51111) & 9,77 & 0,10 & 4,36 & 0 \\
\hline Prirodzené vodné plochy (51211) & 0 & 3,55 & 2,52 & 0 \\
\hline
\end{tabular}

Zdroj: vlastné spracovanie 


\section{Diskusia}

Krajinná pokrývka je v súčasnosti značne rozoberanou témou, čo dokumentuje aj množstvo prác, ktoré sa venujú tejto problematike, prípadne priamo riešia oblast' metodiky skúmania jej zmien. Autorka Kopecká (2006) poskytuje podrobné členenie tried krajinnej pokrývky na piatej hierarchickej úrovni CLC. Dôraz bol v tejto práci kladený najmä na triedy, ktoré majú priamy súvis s využitím krajinnej pokrývky ako agroenvironmentálneho indikátora, prípadne majú význam z hl'adiska ekosystémovej biodiverzity skúmanej oblasti. Čo sa týka samotnej metodiky pri vyčlenení tried piatej hierarchickej úrovne, ak je štvrtá hierarchická úroveň absolútne totožná s piatou, tak štvormiestny kód autorka rozšírila o číslicu 1. Druga, Falt’an a Herichová (2015) vo svojom príspevku navrhli modifikáciu piatej hierarchickej úrovne, pričom dôraz kládli na priestorovú podrobnost', ktorá by umožnila identifikovat' výrazne kontrastné typy krajinnej pokrývky aj v rozdrobenej vidieckej, prípadne poloprírodnej krajine. Autori považujú za významnú skutočnost' identifikáciu tried krajinnej pokrývky na leteckých snímkach vo viditel'nom spektre a ich ciel’om je, aby klasifikácia mala čím menší počet čím homogénnejších tried. Odlišnost' od práce Kopeckej možno pozorovat' aj v prípade zhody štvrtej hierarchickej úrovne s piatou - v tomto prípade autori nepriradili $\mathrm{k}$ štvormiestnemu kódu číslicu 1, ale číslicu 0 . V prípade výskumu krajinnej pokrývky vo vel'kých mierkach sa javí ako vhodné využitie príspevku Ot’ahela et al. (2017), ktorý komplexne zastrešuje rozoberanú problematiku, ked’že podrobne definuje vysvetlivky vzt’ahujúce sa k mapovaniu krajinnej pokrývky vo vel'kých mierkach.

Výskyt konkrétnych tried krajinnej pokrývky je vel’mi rôznorodý, a identifikácia podobnosti s inými prácami zaoberajúcimi sa rovnakou problematikou je častokrát náročná a nie vždy možná, a to najmä z dôvodu rozdielnosti sledovaných území v mnohých parametroch. Podobnost' možno určit' v prípade zväčšujúceho sa počtu tried, ktorý súvisí s podrobnejšou úrovňou mapovania a taktiež možno častokrát identifikovat' zväčšenie plošného zastúpenia sídelnej zástavby, resp. nárast dížky spevnených ciest, avšak konštatovanie z logických dôvodov neplatí pre každé územie. Zároveň je vhodné uviest', že nie je dostupné také množstvo prác, aby bolo možné realizovat' porovnanie a analýzu výsledkov získaných v prípade rovnakého územia pri použití mierne odlišnej metodiky vyhodnotenia a skúmania. Otáznou je iste aj opodstatnenost' štúdií tohto charakteru.

Dôležitým faktom je aj skutočnost', že identifikácia bola realizovaná pomocou vektorizácie mapových podkladov. Skúsenost' autora pri procese vektorizácie môže mat' vplyv na zistené výsledky, avšak je vhodné zdôraznit', že subjektívnost' pri rozhodovaní o priradení konkrétnych prvkov do tried krajinnej pokrývky by mala byt' čo možno najviac potlačená do úzadia a samotné priradenie prvku by malo byt' realizované najmä na základe objektívnych skutočností. Úlohu taktiež môže zohrávat' aj prípadné chýbajúce zaznačenie prvkov na niektorých mapových podkladoch, najmä čo sa týka použitých historických mapových podkladov, a to s prihliadnutím na skutočnost', že takmer každý mapový podklad je jedinečný, najmä v súvislosti so zvolenou metodikou pri jeho tvorbe. $Z$ tohto dôvodu sa javí ako najvhodnejšie použitie leteckých snímok s dostatočným rozlíšením a s prípadnou rekognoskáciou, kde je tento problém významne minimalizovaný. Za zmienku stojí aj fakt, že pri historických mapových podkladoch musíme počítat's generalizáciou ich obsahu prispôsobeného mierke a účelu mapy, čo sa odzrkadl'uje v množstve použitých mapových znakov zastupujúcich reálne objekty a javy v krajine. Je preto vhodné využitie takých podkladov, ktoré boli vyhotovené vo vel'kých mierkach, pričom existuje predpoklad, že pri ich tvorbe nebol výrazne využitý proces generalizácie. $\mathrm{Na}$ druhej strane ortofotosnímky síce zaznamenávajú negeneralizovaný stav krajiny, čím umožňujú identifikovanie pomerne vel'kého množstva tried, avšak s časovým odstupom od ich snímkovania sa znižuje možnost' dodatočnej interpretácie niektorých objektov a vzniká tak možnost' potenciálnej nejednoznačnosti identifikácie a následnej interpretácie, a to najmä kvôli nemožnosti íst' daný skutkový stav obhliadnut'. Túto problematiku je potrebné zdôraznit' 
najmä pri starších ortofotosnímkach. V prípade realizácie nových podkladov je možné uskutočnit' rekognoskáciu pri procese snímkovania a dosiahnut' tak požadovaný výsledok. Ak teda nie je pri nejednoznačných prvkoch uskutočnená rekognoskácia, môže byt’ následná interpretácia zavádzajúca, resp. nepresná. Taktiež zistenie istých vybraných bodových a líniových prvkov krajiny, ktoré klasické topografické mapy zachytávajú, ked’že bol vykonaný aj terénny prieskum, je st’ažené, ak v čase vzniku snímky nebola súčasne urobená aj rekognoskácia terénu. Na zistenie zmien sa dajú využit’ aj staré topografické mapy, ktoré sú už generalizované voči ortofotosnímke, ktorá nie je generalizovaná. Príkladmi objektov, ktoré sú vel'mi t’ažko identifikovatel'né z ortofotosnímok s odstupom času, sú napr. vodné toky a nespevnené cesty $\mathrm{v}$ lesoch.

\section{Záver}

Štúdia prináša pomerne detailnú rekonštrukciu krajinnej pokrývky mestskej časti Bratislava-Devín v priebehu 20. a začiatku 21. storočia, vrátane charakteristiky jednotlivých zmien, ktoré nastali. Na základe analýzy použitých mapových podkladov možno konštatovat', že pre skúmané územie bol v minulosti typický značný výskyt trávnych porastov a ovocných sadov. Avšak zastúpenie ovocných sadov pretrváva dodnes aj napriek skutočnosti, že zaznamenali úbytok takmer v každom sledovanom období, pričom za jeden z podstatných dôvodov môžeme považovat’ nárast zastavanej časti územia. Trávne porasty boli postupom času nahradzované inými triedami krajinnej pokrývky, či už vinicami, nesúvislou sídelnou zástavbou alebo listnatým lesom. Taktiež bol počas sledovaného obdobia zaznamenaný prírastok nesúvislej sídelnej zástavby, ktorý má spojitost' s postupným osídl’ovaním územia počas sledovaného obdobia. Pozoruhodným vývojom prešli aj vinice, ktorých výskyt je datovaný v danom území až v druhej polovici dvadsiateho storočia, pričom následne si zachovali prevažne vel'koplošný charakter. Výrazným prvkom, ktorý má vplyv na celkový charakter územia, je rieka Dunaj, ktorej meandrujúce koryto predstavuje dominantný element mestskej časti. V prípade líniových prvkov bol zaznamenaný kontinuálny nárast spevnenej cestnej siete, čo môžeme pravdepodobne pripísat' rozvoju infraštruktúry v danom území. Na základe uvedeného môžeme konštatovat', že aj v našej štúdii sa vyskytujú zmeny krajinnej pokrývky súvisiace s procesom urbanizácie, a to vo forme prírastku sídelnej zástavby na úkor pol’nohospodárskych areálov; intenzifikáciou pol'nohospodárstva - spôsobenou zmenou ornej pôdy na vinice, resp. ovocné sady; a taktiež zalesnením - premena najmä trávnych porastov na les $\mathrm{v}$ rôznom vývojovom štádiu.

Značnú pozornost' je potrebné venovat' aj výberu podkladov, na základe ktorých je realizovaný výskum krajinnej pokrývky. Je vhodné zdôraznit', že ako najvhodnejší podklad pre výskum zmien krajinnej pokrývky vo vel'kých mierkach sa javí letecká snímka s dostatočnou presnost'ou a rozlišovacou schopnost’ou. V prípade historických máp je žiadúci výber takých podkladov, ktoré boli vyhotovené vo vel'kých mierkach, majú patričnú obsahovú štruktúru a možno na nich jednoznačne interpretovat' jednotlivé prvky v záujmovom území. Historické mapy ZM SR a TM G-K v našom prípade spĺn̆ali vyššie uvedené charakteristiky, a preto sme sa ich rozhodli využit', ked’že ponúkajú hodnoverný obraz krajiny v danom období. V prípade VTM je splnenie týchto podmienok nejednoznačnejšie, z tohto dôvodu možno označit' použitie tohto mapového podkladu ako experimentálne. Avšak v prípade mestskej časti Bratislava-Devín poskytovalo toto mapové dielo dostatok informácií spolu s dostatočnou kvalitou zobrazenia. Na základe uvedeného bolo teda možné zahrnút' aj tento zdroj údajov do výslednej analýzy.

Stanovenie jedného univerzálneho mapového klúča, za predpokladu čo najvernejšieho definovania jednotlivých určujúcich charakteristík územia, je v prípade piatej hierarchickej úrovne CLC značne náročné, ked’že mapový kl'úč je potrebné aplikovat' na výskum, ktorý je realizovaný 
na lokálnej úrovni vo vel'kých mierkach. Náročnost' spočíva najmä v rôznom charaktere sledovaného územia a rôznych diferencií, resp. anomálií, vyskytujúcich sa na danom území, pričom je možné pozorovat' skutočnost', že čím podrobnejšie mapovanie, tým väčší výskyt diferencií.

Neustály vývoj informačných technológií umožňuje podrobnejšie skúmanie krajinnej pokrývky s následnou detailnejšou analýzou zistených výsledkov. Aj tieto skutočnosti majú za následok kladenie dôrazu na mapovanie menších území vo vel'kých mierkach s využitím rozličných podkladov.

\section{Literatúra}

BOLTIŽIAR, M., OLAH, B. 2009: Krajina a jej štruktúra (mapovanie, zmeny a hodnotenie). Nitra (Univerzita Konštantína Filozofa v Nitre, Fakulta prírodných vied).

BOLTIŽIAR, M., OLAH, B., GALLAY, I., GALLAYOVÁ, Z., 2016: Transformation of the Slovak cultural landscape and its recent trends. In Halada, L., Bača, A., Boltižiar, M. eds. Landscape and landscape ecology: proceedings of the 17th International Symposium on Landscape Ecology. Proceedings. Bratislava (Institute of Landscape Ecology SAS), 57-67.

BRACCHETI, L., CAROTENUTO, L., CATORCI, A. 2012: Land-cover changes in a remote area of central Apennines (Italy) and management directions. Landscape and Urban planning, 104(2), 157-170. DOI: https://doi.org/10.1016/j.landurbplan.2011.09.005.

CEBECAUEROVÁ, M., CEBECAUER, T. 2008: Spatio-temporal trends of landscape developenment in southwest part of Slovakia. Ekológia, 27(2), 212-228.

DI GREGORIO, A., O’BRIEN, D. 2012: Overview of land-cover classifications and their interoperability. In Giri, Ch. P. ed. Remote sensing of land use and land cover: Principles and applications. Boca Raton, FL (CRC Press), 37-47.

DOHODNUTÉ ZNAČKY TOPOGRAFICKÝCH MÁP 1959: Dohodnuté značky topografických máp v mierkach 1:10 000 a 1:5 000 (Slovenské znenie), druhé, pozmenené vydanie. Praha (Ústredná správa geodézie a kartografie).

DRUGA, M., FALŤAN, V., HERICHOVÁ, M. 2015: Návrh modifikácie metodiky CORINE Land Cover pre účely mapovania historických zmien krajinnej pokrývky na území Slovenska v mierke 1:10 000 - príkladová štúdia historického k.ú. Batizovce. Geographia Cassoviensis, 9(1), 17-34.

DUBCOVÁ, A. et al. 2013: Didaktika geografie v teréne. Nitra (Univerzita Konštantína Filozofa v Nitre).

FALŤAN, V., BÁNOVSKÝ, M., JANČUŠKA, D., SAKSA, M. 2008: Zmeny krajinnej pokrývky úpätia Vysokých Tatier po veternej kalamite. Bratislava (Geo-grafika).

FALŤAN, V., OŤAHEL', J., GÁBOR, M., RUŽEK, I. 2018: Metódy výskumu krajinnej pokrývky. Bratislava (Univerzita Komenského v Bratislave).

FERANEC, J., OŤAHEL J. 1995: Význam bázy dát projektu Corine Land Cover pre geografiu. Geographia Slovaca, 10, 47-50.

FERANEC, J., OŤAHEL, J. 1999: Mapovanie krajinnej pokrývky metódou Corine v mierke 1:50 000: Návrh legendy pre krajiny programu Phare. Geografický časopis, 51(1), 19-44.

FERANEC, J., OŤAHEL, J. 2001: Krajinná pokrývka Slovenska. Bratislava (VEDA).

GERARD, F., PETIT, S., SMITH, G., THOMSON, A., BROWN, N., MANCHESTER, S. et al. 2010: Land cover change in Europe between 1950 and 2000 determined employing aerial photography. Progress in Physical Geography, 34(2), 183-205. DOI: https:// doi.org/10.1177/0309133309360141.

GOUNDARIDIS, D., APOSTOLOU, A., KOUKOULAS, S. 2015: Land Cover of Greece: a semi-automated classification using random forests. Journal of maps, 10, 1-8. DOI: https://doi.org/10.1080/17445647.2015.1123656. 
GREŽO, H. 2012: Analýza zmien krajinnej štruktúry v rôznych časových obdobiach. In Růžička, J. ed. Zborník GIS Ostrava 2012 - Současné výzvy geoinformatiky. Ostrava (VŠB - Technická univerzita Ostrava). Dostupné na: http://gis.vsb.cz/GIS_Ostrava/GIS_Ova _2012/ sbornik/papers/grezo.pdf.

HUSÁR, K. 1996: Presnost’ digitálnych priestorových údajov. Kartografické listy, 4, 69-78.

IVANOVÁ, M. 2013: Geografické práce 15: Zmeny krajinnej pokrývky zázemia Zemplínskej Širavy v rokoch 1956 - 2009. Prešov (Prešovská univerzita).

IVANOVÁ, M., MICHAELI, E., BOLTIŽIAR, M. 2013: Analýza zmien priestorovej štruktúry krajinnej pokrývky územia severne od vodnej nádrže Zemplínska Š́rava. Geografický časopis, 65(3), 235-250.

IVANOVÁ, M., MICHAELI, E., BOLTIŽIAR, M., FAZEKAŠOVÁ, D. 2013. The analysis of changes ekological stability of landscape in the contrasting region of the mountaina range and a lowland. In 13th SGEM GeoConference on Ecology, Economics, Education And Legislation, SGEM 2013 Conference Proceedings, June 16-22, Vol. 1, pp. 925-938. DOI: https://doi.org/10.5593/SGEM2013/BE5.V1/S20.122.

IZAKOVIČOVÁ, Z., MEDERLY, P., PETROVIČ, F. 2017: Long-Term Land Use Changes Driven by Urbanisation and Their Environmental Effects (Example of Trnava City, Slovakia). Sustainability, 9(9), 1-28. DOI: https://doi.org/10.3390/su9091553.

JANKÓ, A., PORUBSKÁ, B. 2013. Vojenské mapovanie na Slovensku 1769 - 1883. Bratislava (Pamiatkový úrad Slovenskej republiky).

KANDRÍK, R., OLÁH, B. 2010: Land use development in the central part of the Spiš region (Slovakia) since the 18th century. Moravian Geographical Reports, 18(4), 10-20.

KAŇUK, J., GALLAY, M., HOFIERKA, J. 2015: Generating time series of virtual 3-D city models using a retrospective approach. Landscape and Urban Planning, 139, 40-53. DOI: https://doi.org/10.1016/j.landurbplan.2015.02.015.

KOLEJKA, J., MAREK, D. 2004: Identifikace vývojových trendů využití krajiny v odlišných typech př́rodního prostředí. Geografické informácie, 8, 127-135.

KOPECKÁ, M. 2006: Identifikácia a hodnotenie zmien krajiny vo vel'kej mierke (na príklade okolia Trnavy). Geografický časopis, 58(2), 125-148.

LIESKOVSKÝ, J., KAIM, D., BALÁSZ, P. et al.2018: Historical land use dataset of the Carpathian region (1819-1980). Journal of Maps, 14(2), 644-651. DOI: https://doi.org/10.1080/ 17445647.2018.1502099.

MIČIETOVÁ, E., KOŽUCH, M. 2008: Špecializované informačné technológie v prírodovednom výskume: Geoinformačné technológie. Bratislava (Elita).

MORAVČÍK, F. 2017: Zmeny krajinnej pokrývky mestskej časti Bratislava-Devín na starých mapách - bakalárska práca. Bratislava (Prírodovedecká fakulta, Univerzita Komenského v Bratislave).

MUNTEANU, C., KUEMMERLE, T., BOLTIŽIAR, M. et al. 2017: Nineteenth-century landuse legacies affect contemporary land abandonment in the Carpathians. Regional Environmental Change, 11(8), 2209-2222. DOI: https://doi.org/10.1007/s10113-016-1097-X.

OLAH, B. 2005: Kultúrna krajina Banskej Štiavnice a jej premeny. Sborník prací Pedagogické fakulty Masarykovy Univerzity, 183(25), 586-596.

ORTOFOTOMAPA 2005: Ortofotomapa () Geodis Slovakia, s. r. o., Banská Bystrica. Letecké snímkovanie a Digitálna ortofotomapa (C) Eurosense s. r. o., Bratislava.

OŤAHEL, J., FERANEC, J., KOPECKÁ, M., FALŤAN, V. 2017: Modifikácia metódy Corine Land Cover pre identifikáciu a zaznamenávanie tried krajinnej pokrývky v mierke 1:10 000 na báze príkladových štúdií z územia Slovenska. Geografický časopis, 69(3), 189-224. 
PAZÚR, R., BOLLIGER, J. 2017: Land changes in Slovakia: past processes and future directions. Applied Geography, 85, 163-185. DOI: https://doi.org/10.1016/j.apgeog.2017.05.009.

PRAVDA, J. 2003: Mapový jazyk. Bratislava (Univerzita Komenského v Bratislave).

RÁBEKOVÁ, A. 2008: Zmeny krajiny po roku 1949 v lokalite Devínske jazero (Bratislava). Geographia Cassoviensis, 1(2), 142-145.

WMS SAŽP 2018: WMS Slovenskej agentúry životného prostredia. Banská Bystrica (SAŽP) Dostupné na: http://nipi.sazp.sk/arcgis/services/ng/rastre/MapServer/WMSServer.

ZBGIS 2009: Základná báza údajov pre geografický informačný systém. Bratislava (Úrad geodézie, kartografie a katastra Slovenskej republiky).

ZBGIS 2018: Vol’ne dostupné WMS služby zo ZBGIS. Bratislava (Úrad geodézie, kartografie a katastra Slovenskej republiky). Dostupné na: https://www.geoportal.sk/sk/sluzby/mapove-sluzby/wms/wms-zbgis.html.

ZHORELA, P. 1949: Náuka o mapách a teréne. Bratislava (Štátne nakladatel'stvo).

ZOZNAM MAPOVÝCH ZNAČIEK 1972: Základná mapa ČSSR 1:10 000, Zoznam mapových značiek (Príloha 1 k Smerniciam pre tvorbu základnej mapy ČSSR 1: 10 000). Bratislava (Slovenská správa geodézie a kartografie).

Pod'akovanie: Práca vznikla vd'aka podpore v rámci OP Výskum a vývoj pre dopytovo-orientovaný projekt: Univerzitný vedecký park Univerzity Komenského v Bratislave, ITMS 26240220086, 2. Fáza ITMS 313021D075, spolufinancovaný zo zdrojov Európskeho fondu regionálneho rozvoja.

\section{Adresy autorov}

Mgr. Filip Moravčík

Katedra kartografie, geoinformatiky a dial'kového prieskumu Zeme

Prírodovedecká fakulta, Univerzita Komenského v Bratislave

Mlynská dolina, Ilkovičova 6

84215 Bratislava

Slovensko

moravcik48@uniba.sk

Mgr. Alexandra Benová, PhD.

Katedra kartografie, geoinformatiky a dial'kového prieskumu Zeme

Prírodovedecká fakulta, Univerzita Komenského v Bratislave

Mlynská dolina, Ilkovičova 6

84215 Bratislava

Slovensko

alexandra.benova@uniba.sk 